\title{
ANALISIS KUALITAS PELAYANAN INTERNET INDIHOMEPADA PT. X DENGAN PENDEKATAN PART LEAST SQUARE
}

\author{
Kukuh Winarso $^{1}$, Moh. Jufriyanto ${ }^{2}$, Helmy Yahya $^{3}$ \\ Program Studi Teknik Industri Fakultas Teknik \\ Universitas Trunojoyo Madura ${ }^{1}$ \\ Program Studi Teknik Industri Fakultas Teknik \\ Universitas Muhammadiyah Gresik ${ }^{2}$ \\ Program Studi Teknik Industri Fakultas Teknik \\ Universitas Trunojoyo Madura ${ }^{3}$ \\ Kukuhutm@gmail.com ${ }^{1}$, Jufriyanto@umg.ac.id ${ }^{2}$
}

\begin{abstract}
ABSTRAK
$\mathrm{P}$ T. X menyediakan layanan internet berbayar yang dikenal dengan indihome. Permasalahan yang terjadi di layanan internet Indihome adalah terdapat sebesar 42,36\% komplain dari konsumen terhadap proses pelayanan yang diberikan oleh PT. X dan terdapat 7,46\% komplain mengenai jumlah tagihan. Tujuan dari penelitian ini adalah memodelkan dan mengetahui variabel apa saja yang mempengaruhi kualitas layanan internet indihome. Metode yang digunakan adalah Partial Least Square (PLS). Partial Least Square (PLS) adalah salah satu teknik analisis statistika multivariat yang dapat menangani banyak variabel respon dan sekaligus variabel eksplanatori. Variabel yang digunakan adalah tangible, empathy, assurance, reliability dan responsiveness. Hasil penelitian yaitu terdapat peningkatan nilai $R$ square setelah dilakukan pengeliminasian pada indikator A5 yang tidak memenuhi model PLS Kelima variabel dalam mempengaruhi kualitas layanan internet indihome sebesar 76,1\%. Berdasarkan hasil uji hipotesis pada model outer dikatakan bahwa indikator variabel valid dengan nilai $p$-value $=0$ $<0,05$. Pada pengujian model inner diperoleh bahwa variabel tangible dan responsiveness tidak berpengaruh signifikan pada kualitas layanan internet indihome, sedangkan variabel empathy, assurance, reliability berpengaruh signifikan pada kualitas layanan internet indihome.
\end{abstract}

Kata Kunci :Partial Least Square,Kualitas Layanan, Internet, Internet Indihome

\section{PENDAHULUAN}

Internet merupakan hubungan berbagai perangkat komputer dan jaringan di dunia yang memiliki perbedaan pada sistem operasi maupun aplikasi yang digunakan dengan memanfaatkan hubungan antara kemajuan media komunikasi (telepon dan satelit) yang menggunakan protokol standar dalam komunikasi yaitu protokol TCP/IP yang berisikan informasi dan sebagai sarana komunikasi data yang dapat berupa suara, gambar, video dan juga teks (Mardiana dan Rubiyanti, 2017).Perkembangan dan perubahan gaya hidup masyarakat, kebutuhan akan akses informasi dan komunikasi yang beragam, mudah dan cepat merupakan sebuah kebutuhan manusia untuk berinteraksi dengan sesama dan dengan lingkungannya (Nugroho, 2014).

Dalam menghadapi kebutuhan akan akses informasi yang cepat dan mudah, maka PT. X menyediakan layanan internet berbayar yang dikenal dengan indihome. Kelebihan internetindihome dalam segi jaringan lebih kuat dan stabil apabila dibandingkan dengan jaringan coaxial dengan kecepatan maksimal yaitu sebesar 5 mbps sedangkan jaringan yang digunakan oleh internetindihome merupakan Fiber Optic yang mampu memberikan kecepatan hingga 100 mbps dan lebih stabil apabila digunakan pada saat cuaca 
buruk, dan tidak akan merusak perangkat apabila petir masuk ke saluran kabel.Produk ini merupakan produk layanan akses internet broadband berkecepatan tinggi. Semakin Ketatnya persaingan antar provider jasa telekomunikasi membuat PT. X untuk berinovasi dengan menyediakan layanan fasilitas komunikasi untuk memenuhi kebutuhan konsumen dengan jalan menyediakan layanan yang beragam yaitu diantaranya adalah layanan komunikasi suara (Telepon), Internet Fiber dan TV berlangganan (Usee TV) dan sebagainya.

Permasalahan yang terjadi di layanan internetIndihome adalah terdapat sebesar $42,36 \%$ komplain dari konsumen terhadap proses pelayanan yang diberikan oleh PT. Xdan terdapat $7,46 \%$ komplain mengenai jumlah tagihan (Amatullah dan Widaningsih, 2017). Hal tersebut menyebabkan penurunan pengguna internetIndihome yang dapat diketahui dari market share mulai tahun 2016 hingga 2018. Pelanggan internetindihome pada 3 tahun terakir mengalami fluktuasi. Tahun 2016 terdapat 48,1\% pengguna internet indihome dan di tahun 2017 mengalami peningkatan menjadi 50,3\% dan pada tahun 2018 megalami penurunan kembali menjadi $42,1 \%$. Hal ini menunjukkan bahwa secara umum internetindihome belum dapat memuaskan konsumen karena penggunanya yang relatif mengalami fluktuasi.. Oleh karena itu maka dilakukan penelitian pada PT. X mengenai kualitas pelayanan tentang produk intentet indihome.

\section{TINJAUAN PUSTAKA}

\subsection{Kualitas Layanan}

Menurut Lupiyoadi (2001) dalam penelitian
Razak dan Finnora (2017) dijelaskan bahwa definisi kualitas layanan (servicequality) merupakan keseluruhan ciri-ciri dan karakteristik-karakteristik dari kemampuan sebuah produk ataupun jasa dalam hal untuk memenuhi kebutuhan-kebutuhan yang telah ditentukan. Kualitas layanan merupakan upaya untuk memberikan kesempurnaan pelayanan yang dilakukan oleh penyedia layanan maupun jasa dalam upaya untuk memenuhi kebutuhan dan keinginan konsumen serta ketepatan penyampaiannya untuk dapat mengimbangi harapan konsumen. Kualitas layanan tidak ditinjau berdasarkan sudut pandang pelanggan, yakni layanan yang diharapakan (expected service) dan layanan yang dirasakan (perceived service) (Pertiwi, 2017). Menurut Gulla, Oroh dan Roring (2015), menyatakan bahwa kualitas pelayanan adalah unsur penentu bagi perusahaan dalam mempertahankan konsumen, dimana untuk mewujudkan rasa nyaman dan memiliki nilai lebih yang diharapkan. Menurut Tjiptono (2007) dalam Panjaitan dan Yuliati (2016) menyatakan bahwa kualitas pelayanan adalah upaya pemenuhan kebutuhan dan keinginan serta ketepatan dalam mengimbangi harapan konsumen.

\subsection{Kepuasan Konsumen}

Kepuasan konsumen merupakan sebuah hasil kesesuaian dengan harapan yang dirasakan oleh pengguna produk maupun jasa dari kinerja sebuah perusahaan. Konsumen akan merasa puas apabila harapan mereka dapat terpenuhi, dan merasa gembira apabila harapan dapat terlampaui (Putri dan Widodo, 2016). Kepuasan konsumen adalah perasaan atau sikap pelanggan terhadap produk atau pelayanan jasa setelah penggunaan produk atau pelayanan tertentu (Nugroho, 2014). Menurut Bailia, Soegoto dan Loindong (2014), kepuasan konsumen merupakan rasa senang atau kecewa yang timbul karena 
membandingkan kinerja dengan ekspektasi yang dilakukan oleh konsumen. Assauri (2012) dalam Moha dan Loindong (2016) menyatakan bahwa kepuasan konsumen adalah suatu indikator akan keberhasilan bisnis perusahaan tentang tanggapan pelanggan untuk masa depan bisnis perusahaan.

\subsection{Partial Least Square}

PLS adalah sebuah pendekatan pemodelan kausal yang memiliki tujuan untuk memaksimumkan variansi dari variabel laten kriteria yang dapat dijelaskan (explained variance) oleh variabel laten prediktor, sedangkan tujuan daricovariance-based structural equation modeling(CB-SEM) adalah menghasilkan matriks kovarians teoritis (theoritical covarians matrix) tanpa terfokus pada explained variance (Mahfud dan Ratmono, 2013:3). Partial Least Square dikembangkan pertama kali oleh Herman Wold pada tahun 1966 sebagai sebuah metode yang bersifat umum untuk mengestimasi path model yang menggunakan kontruk laten dengan

\section{. Model PLS}

Pembuatan model awal PLS digunakan untuk memberikan gambaran kerangka konsep yang menunjukkan hubungan antar variabel laten dari hasil studi literatur dan presamplingyang telah dilakukan. multiple indikator (Ghozali, 2014 : 29).

PLS (Partial Least Square) merupakan sebuah metode yang digunakan untuk penciptaan dan pembangunan model dengan menggunakan pendekatan yang memiliki orientasi pada prediksi (Shandyastini, 2016). Penggunaan PLS dalam penelitian ini karena model yang dibentuk optimal dalam ketepatan prediksi dan memiliki komplektisitas yang besar, selain itu penggunaan PLS membutuhkan sampel yang tidak terlalu besar yaitu 30 sampai 100.

\section{METODOLOGI PENELITIAN}

\subsection{Rancangan Kuesioner}

Kuesioner digunakan sebagai alat ukur untuk menilai kepuasan konsumen Indihome dengan mencakup lima dimensi yaitu Tangibles, Empathy, Assurance, Reliability dan

\section{Responsiveness}

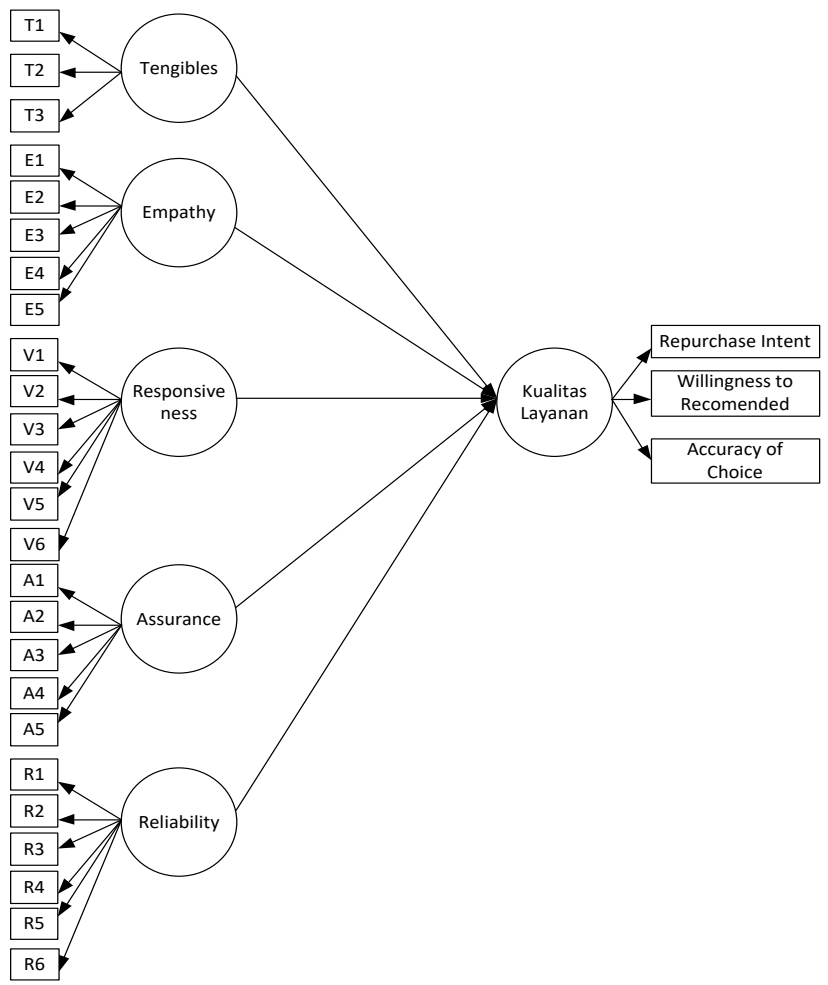

Gambar 1. Model PLS 


\subsection{Hipotesis Penelitian}

Pengujian hipotesis dilakukan pada outer dan inner model yang telah dibuat.

1. Hipotesis outer model digunakan untuk mengetahui apakah indikator variabel bersifat valid atau tidak. Adapun hipotesis yang digunakan adalah sebagai berikut :

H0 $: X i=0$ (Indikator ke- $i$ tidak signifikan)

$\mathrm{H} 1: X i \neq 0$ (Indikator ke- $i$ signifikan)

2. Hipotesis inner model digunakan untuk mengetahui apakah variabel eksogen memiliki pengaruh yang signifikan terhadap kualias layanan. Adapun hipotesis yang digunakan adalah sebagai berikut:

HO : $Y i=0$ (Variabel eksogen ke- $i$ tidak berpengaruh signifikan terhadap kualitas layanan internet indihome)

H1 : $Y i \neq 0$ (Variabel eksogen ke- $i$ berpengaruh signifikan terhadap kualitas layanan internet indihome).

\subsection{Metode Penyelesaian}

Metode penyelesaian sebagai berikut :

1. Uji validitas kusioner

Uji validitas digunakan untuk mengukur sejauh mana ketepatan dan kecermatan dari alat ukur (kuesioner) yang digunakan dalam melakukan pengukuran sesuatu yang hendak diukur. Pengujian validitas dilakukan dengan menggunakan Software SPSS dengan cara membandingkan nilai korelasi dari hasil output SPSS dengan nilai korelasi tabel.

2. Uji reliabilitas kuesioner

Uji reliabilitas digunakan untuk mengukur konsistensi alat ukur penelitian (kuesioner) bila pengukuran dilakukan secara berulang kali. Jila nilai $r$ hitung $>0,6$ maka alat ukur dikatakan reliabel dan mampu memberikan hasil pengukuran yang konsisten.

\section{Metode PLS}

Berikut merupakan langkah serta pengerjaan dengan menggunakan metode PLS:

a. Melakukan konseptualisasi model PLS yang telah dibuat

b. Melakukan penggambaran diagram jalur dengan efek mediasi

c. Melakukan Pengujian Confirmatory Factor Analysis yang meliputi outer model atau model pengukuran dan inner model atau model struktural, validitas deskriminan dan reliabilitas. Convergent validity dari model pengukuran dinilai berdasarkan besarnya korelasi yang terbentuk antara item scorelcomponent score dengan construct score yang dihitung dengan PLS. Ukuran raflektif individual dapat disebut tinggi apabila nilai korelasi 0,70 dengan konstruk yang ingin diukur, namun nilai pengukuran loading 0,5 sampai 0,6 dianggap cukup dalam tahap awal pengembangan skala pengukuran (Ghozali, 2014:39). Discriminant validity dari model pengukuran dinilai dari cross loading pengukuran dengan konstruk. Metode lain yang dapat digunakan untuk mengukur discriminant validity adalah dengan membandingkan nilai square root of average varianceextracted (AVE) setiap konstruk dengan korelasi antar konstruk dalam model. Jika nilai akar kuadrat AVE setiap konstruk lebih besar dari pada nilai korelasi antar konstruk maka dikatakan jika nilai discriminnat validity yang baikdan direkomendasikan jika nilai AVE 
Winarso $^{1}$, Jufriyanto ${ }^{2}$, Yahya ${ }^{3}$ / MATRIK Vol. XX Vol 1 September 2019 p:77-87

lebih besar dari 0,5 (Ghozali, 2014 :

40)

d. Melakukan evaluasi inner model (model struktural) dengan metode resampling yang digunakan untuk mengetahui signifikansi pengaruh antar variabel dengan menggunakan metode bootstrapping.

e. Melakukan analisa GoF (Goodness FitIndex) untuk mengevaluasi model pengukuran dan model struktural dan pengukuran sederhana untuk keseluruhan prediksi model.

\section{HASIL DAN PEMBAHASAN}

\subsection{Rekap Profil Responden}

Berikut merupakan rekapan profil responden dari penelitian ini yaitu :

Tabel 1. profil responden

\begin{tabular}{|c|c|c|c|c|}
\hline Profil & Keterangan & Jumlah & Total & Persentase \\
\hline \multirow{2}{*}{ Usia } & $\geq 35$ Tahun & 120 & \multirow{2}{*}{162} & $74.07 \%$ \\
\hline & $<35$ Tahun & 42 & & $25.93 \%$ \\
\hline \multirow{2}{*}{ Jenis Kelamin } & Laki-laki & 130 & \multirow{3}{*}{162} & $80.25 \%$ \\
\hline & Perempuan & 32 & & $19.75 \%$ \\
\hline \multirow{5}{*}{ Pekerjaan } & Karyawan & 31 & & $19.14 \%$ \\
\hline & Wiraswasta & 90 & \multirow{4}{*}{162} & $55.56 \%$ \\
\hline & TNI/POLRI & 8 & & $4.94 \%$ \\
\hline & PNS & 30 & & $18.52 \%$ \\
\hline & Lainnya & 3 & & $1.85 \%$ \\
\hline \multirow{4}{*}{ Pendidikan Terakhir } & SD & 0 & \multirow{4}{*}{162} & $0.00 \%$ \\
\hline & SMP & 5 & & $3.09 \%$ \\
\hline & SMA & 98 & & $60.49 \%$ \\
\hline & Sarjana & 59 & & $36.42 \%$ \\
\hline \multirow{5}{*}{ Pendapatan } & Rp1.500.000 s/d Rp2.500.000 & 8 & \multirow{5}{*}{162} & $4.94 \%$ \\
\hline & Rp2.600.000 s/d Rp3.500.000 & 31 & & $19.14 \%$ \\
\hline & Rp3.600.000 s/d Rp4.500.000 & 93 & & $57.41 \%$ \\
\hline & Rp4.600.000 s/d Rp5.500.000 & 19 & & $11.73 \%$ \\
\hline & Di atas Rp5.500.000 & 11 & & $6.79 \%$ \\
\hline
\end{tabular}

Dari tabel 1 dijelaskan contoh untuk responden yang memiliki usia > 35 tahun yang berpartisipasi sebesar 120 orang atau $74,07 \%$.

\subsection{Uji Validitas Kuesioner}

Berikut hasil uji validitas yang dilakukan pada kueisioner penelitian ini yaitu :
Tabel 2. Hasil uji validitas

\begin{tabular}{|c|c|c|c|c|c|}
\hline No & Atribut & sig & $</>$ & sig (2-tailed) & Kesimpulan \\
\hline 1 & P1 & 0.05 & $>$ & 0.001 & Valid \\
\hline 2 & P2 & 0.05 & $>$ & 0.000 & Valid \\
\hline 3 & P3 & 0.05 & $>$ & 0.037 & Valid \\
\hline 4 & T1 & 0.05 & $>$ & 0.036 & Valid \\
\hline 5 & T2 & 0.05 & $>$ & 0.018 & Valid \\
\hline 6 & T3 & 0.05 & $>$ & 0.000 & Valid \\
\hline 7 & R1 & 0.05 & $>$ & 0.004 & Valid \\
\hline 8 & R2 & 0.05 & $>$ & 0.003 & Valid \\
\hline 9 & R3 & 0.05 & $>$ & 0.015 & Valid \\
\hline 10 & R4 & 0.05 & $>$ & 0.000 & Valid \\
\hline 11 & R5 & 0.05 & $>$ & 0.001 & Valid \\
\hline 12 & R6 & 0.05 & $>$ & 0.029 & Valid \\
\hline 13 & V1 & 0.05 & $>$ & 0.015 & Valid \\
\hline 14 & V2 & 0.05 & $>$ & 0.013 & Valid \\
\hline 15 & V3 & 0.05 & $>$ & 0.028 & Valid \\
\hline 16 & V4 & 0.05 & $>$ & 0.005 & Valid \\
\hline 17 & V5 & 0.05 & $>$ & 0.029 & Valid \\
\hline 18 & V6 & 0.05 & $>$ & 0.005 & Valid \\
\hline 19 & A1 & 0.05 & $>$ & 0.001 & Valid \\
\hline 20 & A2 & 0.05 & $>$ & 0.007 & Valid \\
\hline 21 & A3 & 0.05 & $>$ & 0.023 & Valid \\
\hline 22 & A4 & 0.05 & $>$ & 0.002 & Valid \\
\hline 23 & A5 & 0.05 & $>$ & 0.017 & Valid \\
\hline 24 & E1 & 0.05 & $>$ & 0.005 & Valid \\
\hline 25 & E2 & 0.05 & $>$ & 0.014 & Valid \\
\hline 26 & E3 & 0.05 & $>$ & 0.003 & Valid \\
\hline 27 & E4 & 0.05 & $>$ & 0.015 & Valid \\
\hline 28 & E5 & 0.05 & $>$ & 0.000 & Valid \\
\hline & & & & & \\
\hline
\end{tabular}

Dari tabel 2 dapat diketahui keseluruhan nilai sig (2-tailed) pada pertanyaan yang ada dalam kuesioner bernilai di bawah 0,05 sehingga dapat dikatakan keseluruhan pertanyaan di dalam kuesioner bersifat valid.

\subsection{Uji Reliabilitas Kuesioner}

Berikut hasil uji reliabilitas yang dilakukan pada kueisioner penelitian ini yaitu :

Tabel 3. Hasil uji reliabilitas

\begin{tabular}{|c|c|}
\hline Cronbach's Alpha & N of Items \\
\hline 0.739 & 29 \\
\hline
\end{tabular}

Berdasarkan tabel 3 dengan pengolahan software SPSS dapat diketahui nilai reliabilitas kuesioner adalah sebesar 0,739 dan dapat dikatakan bahwa kuesioner memiliki tingkat reliabilitas tinggi.

\subsection{Analisis Partial Least Square}

Hasil analisis model awal dari penelitiian sebagai berikut : 


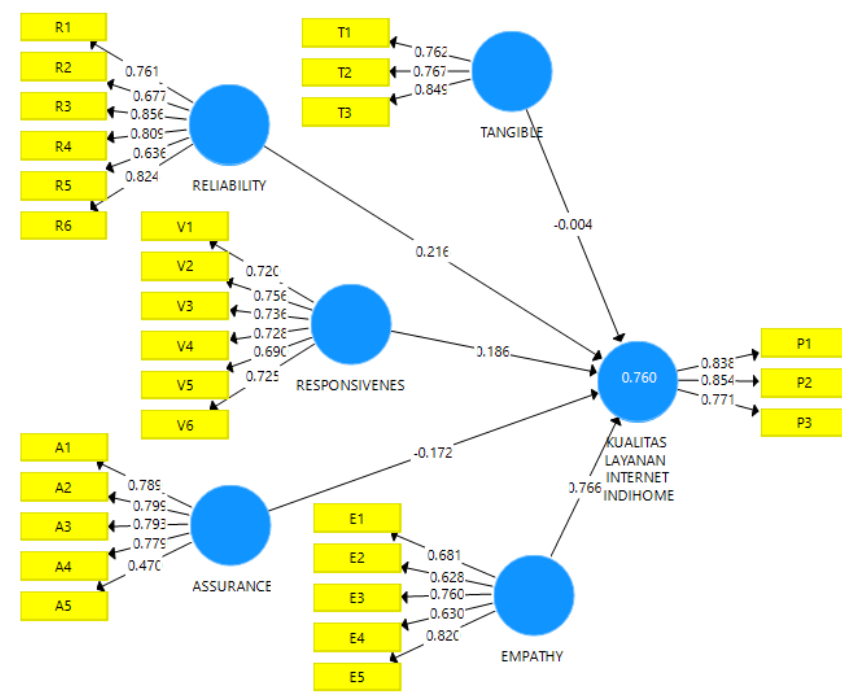

Gambar 2. Hasil model awal PLS

Berdasarkan gambar 2 diketahui model awal dari hasil PLS, dimana nilai $R$-square atau besar pengaruh variabel tangible, reliability, responseiveness, assurance dan empathy terhadap kualitas pelayanan sebesar 0,760 atau 76\%, sedangkan sisanya yaitu $24 \%$ berasar dari variabel lain diluar model.

\subsubsection{Pengujian Outer Model}

a. Convergent Validity

Pengujian convergent validity digunakan untuk melihat nilai korelasi antara indikator dengan konstruknya. Indikator akan dikatakan reliabel jika memiliki nilai yang minimal sebesar 0,5 dan apabila terdapat nilai indikator yang berada di bawah nilai 0,5 indikator tersebut akan dieliminasi dari model. Berikut hasilnya :
Tabel 4. Hasil convergent validity

\begin{tabular}{|c|c|c|c|c|}
\hline No & Indikator & Konstruk & Nilai Outer Loading & Kesimpulan \\
\hline \begin{tabular}{|l|}
1 \\
\end{tabular} & $\mathrm{P} 1$ & \multirow{3}{*}{$\begin{array}{l}\text { Kualitas Layanan } \\
\text { Internet Indihome }\end{array}$} & 0.838 & Memenuhi \\
\hline \begin{tabular}{|l|}
2 \\
\end{tabular} & $\mathrm{P} 2$ & & 0.854 & Memenuhi \\
\hline 3 & P3 & & 0.771 & Memenuhi \\
\hline \begin{tabular}{|l|}
4 \\
\end{tabular} & $\mathrm{~T} 1$ & \multirow{3}{*}{ Tangible } & 0.762 & Memenuhi \\
\hline 5 & $\mathrm{~T} 2$ & & 0.767 & Memenuhi \\
\hline 6 & $\mathrm{~T} 3$ & & 0.849 & Memenuhi \\
\hline 7 & $\mathrm{R} 1$ & \multirow{6}{*}{ Reliability } & 0.761 & Memenuhi \\
\hline 8 & R2 & & 0.677 & Memenuhi \\
\hline \begin{tabular}{|l|}
9 \\
\end{tabular} & R3 & & 0.856 & Memenuhi \\
\hline 10 & $\mathrm{R} 4$ & & 0.809 & Memenuhi \\
\hline 11 & R5 & & 0.636 & Memenuhi \\
\hline \begin{tabular}{|l|}
12 \\
\end{tabular} & R6 & & 0.824 & Memenuhi \\
\hline 13 & V1 & \multirow{6}{*}{ Responsiveness } & 0.720 & Memenuhi \\
\hline 14 & V2 & & 0.756 & Memenuhi \\
\hline 15 & V3 & & 0.736 & Memenuhi \\
\hline \begin{tabular}{|l|}
16 \\
\end{tabular} & V4 & & 0.728 & Memenuhi \\
\hline 17 & V5 & & 0.690 & Memenuhi \\
\hline 18 & V6 & & 0.725 & Memenuhi \\
\hline 19 & $\mathrm{~A} 1$ & \multirow{5}{*}{ Assurance } & 0.789 & Memenuhi \\
\hline 20 & $\mathrm{~A} 2$ & & 0.799 & Memenuhi \\
\hline 21 & A3 & & 0.793 & Memenuhi \\
\hline \begin{tabular}{|l|}
22 \\
\end{tabular} & $\mathrm{~A} 4$ & & 0.779 & Memenuhi \\
\hline 23 & A5 & & 0.470 & Tidak Memenuhi \\
\hline 24 & E1 & \multirow{5}{*}{ Empathy } & 0.681 & Memenuhi \\
\hline 25 & E2 & & 0.628 & Memenuhi \\
\hline 26 & E3 & & 0.760 & Memenuhi \\
\hline 27 & $\mathrm{E} 4$ & & 0.630 & Memenuhi \\
\hline 28 & E5 & & 0.820 & Memenuhi \\
\hline
\end{tabular}

Berdasarkan tabel 4 dapat diketahui bahwa terdapat satu indikator yang memiliki nilai kurang dari 0,5 yaitu pada indikator A5 pada konstruk Assurance sehingga indikator A5 harus dihapus dari model.

\section{b. Discriminant Validity}

Pengujian discriminant validity digunakan untuk menunjukkan bahwa konstruk dapat memprediksi indikator pada blok mereka sendiri lebih baik apabila dibandingkan dengan indikator pada blok lain. Nilai discriminant validity dapat dilihat dari nilai cross loading pada output software SmartPLS. Berikut hasilnya yaitu 
Tabel 5. Hasil cross loading

\begin{tabular}{|c|c|c|c|c|c|c|}
\hline & Assurance & Empathy & $\begin{array}{c}\text { Kualitas Layanan } \\
\text { Internet Indihome }\end{array}$ & Reliability & $\begin{array}{c}\text { Responsiven } \\
\text { ess }\end{array}$ & Tangible \\
\hline A1 & $\mathbf{0 , 7 8 9}$ & 0,528 & 0,491 & 0,63 & 0,571 & 0,505 \\
\hline A2 & $\mathbf{0 , 7 9 9}$ & 0,477 & 0,487 & 0,599 & 0,626 & 0,471 \\
\hline A3 & $\mathbf{0 , 7 9 3}$ & 0,319 & 0,369 & 0,612 & 0,661 & 0,555 \\
\hline A4 & $\mathbf{0 , 7 7 9}$ & 0,368 & 0,387 & 0,633 & 0,681 & 0,618 \\
\hline A5 & $\mathbf{0 , 4 7}$ & 0,069 & 0,178 & 0,437 & 0,403 & 0,418 \\
\hline E1 & 0,349 & $\mathbf{0 , 6 8 1}$ & 0,608 & 0,291 & 0,312 & 0,249 \\
\hline E2 & 0,302 & $\mathbf{0 , 6 2 8}$ & 0,555 & 0,276 & 0,207 & 0,189 \\
\hline E3 & 0,395 & $\mathbf{0 , 7 6}$ & 0,615 & 0,32 & 0,311 & 0,276 \\
\hline E4 & 0,365 & $\mathbf{0 , 6 3}$ & 0,473 & 0,145 & 0,213 & 0,155 \\
\hline E5 & 0,442 & $\mathbf{0 , 8 2}$ & 0,677 & 0,359 & 0,319 & 0,235 \\
\hline P1 & 0,466 & $\mathbf{0 , 7 2 8}$ & $\mathbf{0 , 8 3 8}$ & 0,527 & 0,441 & 0,352 \\
\hline P2 & 0,514 & 0,692 & $\mathbf{0 , 8 5 4}$ & 0,486 & 0,51 & 0,472 \\
\hline P3 & 0,359 & 0,63 & $\mathbf{0 , 7 7 1}$ & 0,315 & 0,35 & 0,275 \\
\hline R1 & 0,608 & 0,326 & 0,423 & $\mathbf{0 , 7 6 1}$ & 0,631 & 0,687 \\
\hline R2 & 0,478 & 0,196 & 0,337 & $\mathbf{0 , 6 7 7}$ & 0,58 & 0,767 \\
\hline R3 & 0,684 & 0,343 & 0,473 & $\mathbf{0 , 8 5 6}$ & 0,759 & 0,669 \\
\hline R4 & 0,677 & 0,352 & 0,428 & $\mathbf{0 , 8 0 9}$ & 0,708 & 0,537 \\
\hline R5 & 0,571 & 0,319 & 0,364 & $\mathbf{0 , 6 3 6}$ & 0,597 & 0,511 \\
\hline R6 & 0,589 & 0,296 & 0,463 & $\mathbf{0 , 8 2 4}$ & 0,693 & 0,666 \\
\hline T1 & 0,592 & 0,271 & 0,347 & 0,647 & 0,629 & $\mathbf{0 , 7 6 2}$ \\
\hline T2 & 0,478 & 0,196 & 0,337 & 0,677 & 0,58 & $\mathbf{0 , 7 6 7}$ \\
\hline T3 & 0,559 & 0,283 & 0,386 & 0,659 & 0,702 & $\mathbf{0 , 8 4 9}$ \\
\hline V1 & 0,606 & 0,291 & 0,355 & 0,601 & $\mathbf{0 , 7 2}$ & 0,521 \\
\hline V2 & 0,586 & 0,331 & 0,477 & 0,651 & $\mathbf{0 , 7 5 6}$ & 0,639 \\
\hline V3 & 0,604 & 0,274 & 0,396 & 0,694 & $\mathbf{0 , 7 3 6}$ & 0,546 \\
\hline V4 & 0,596 & 0,241 & 0,356 & 0,606 & $\mathbf{0 , 7 2 8}$ & 0,607 \\
\hline V5 & 0,566 & 0,309 & 0,348 & 0,619 & $\mathbf{0 , 6 9}$ & 0,614 \\
\hline V6 & 0,534 & 0,242 & 0,356 & 0,607 & $\mathbf{0 , 7 2 5}$ & 0,575 \\
\hline & & & & & & \\
\hline
\end{tabular}

Dari tabel 5 dapat dijelaskan bahwa nilai masing-masing konstruk yang dicetak dengan huruf tebal dapat memprediksi indikator pada blok mereka sendiri,dan memiliki nilai konstruk lebih baik apabila dibandingkan dengan indikator pada blok lain.

\section{c. Construct Reliability}

Pengujian reliabilitas konstruk dilakukan dengan memperhatikan nilai composite reliability dan cronbach's alpha sedangkan untuk uji validitas konstruk dapat dilihat pada nilai AVE. Nilai cronbach's alpha harus memiliki nilai minimal 0,7 untuk dapat dikatakan reliabel dan untuk uji validitas konstruk dilihat melalui nilai AVE yang harus melebihi nilai 0,5. Berikut merupakan hasilnya :

Tabel 6. Rekap Construct Reliability dan Validity

\begin{tabular}{|l|c|c|c|}
\hline \multicolumn{1}{|c|}{ Konstruk } & $\begin{array}{c}\text { Cronbach's } \\
\text { Alpha }\end{array}$ & $\begin{array}{c}\text { Composite } \\
\text { Reliability }\end{array}$ & $\begin{array}{c}\text { Average Variance } \\
\text { Extracted(AVE) }\end{array}$ \\
\hline Assurance & 0,787 & 0,853 & 0,544 \\
\hline Empathy & 0,747 & 0,832 & 0,501 \\
\hline Kualitas Layanan Internet Indihome & 0,759 & 0,862 & 0,675 \\
\hline Reliability & 0,855 & 0,893 & 0,584 \\
\hline Responsiveness & 0,821 & 0,870 & 0,527 \\
\hline Tangible & 0,705 & 0,836 & 0,630 \\
\hline
\end{tabular}

Berdasarkan tabel 6 dapat diketahui jika seluruh nilai cronbach's alpa pada semua konstruk memiliki nilai di atas 0,7 sehingga dapat dikatakan jika seluruh konstruk bersifat reliabel, sedangkan untuk uji validitas konstruk diketahui jika keseluruhan konstruk memiliki nilai AVE di atas nilai 0,5 dan memenuhi uji validitas konstruk.

\subsubsection{Pengujian Inner Model}

a. $R$-Square

$R$ square digunakan untuk melihat besarnya pengaruh dari sebuah indikator terhadap konstruk endogen maupun konstruk eksogen. Besarnya nlai $R$ square model awal PLS adalah sebesar 0,760 .

b. $f$-square model awal

Nilai $f$ square model digunakan untuk mengetahui besarnya effect size variabel laten endogen terhadap variabel laten eksogen. Apabila nilai $f$ square sama dengan 0,35 maka dapat diinterpretasikan bahwa prediktor variabel laten memiliki pengaruh besar, apabila bernilai sama dengan 0,15 maka memiliki pengaruh menengah dan apabila bernilai sama dengan 0,02 maka memiliki pengaruh kecil (Ghozali, 2014).

Tabel 7. Hasil $f$ square indikator

\begin{tabular}{|l|c|}
\hline \multicolumn{1}{|c|}{ Indikator } & $\begin{array}{c}\text { Kualitas Layan Internet } \\
\text { Indihome }\end{array}$ \\
\hline Assurance & 0,034 \\
\hline Empathy & 1,754 \\
\hline Reliability & 0,035 \\
\hline Responsiveness & 0,028 \\
\hline Tangible & 0,000 \\
\hline
\end{tabular}

Berdasarkan tabel 7 dapat diketahui jika indikator empathy memiliki nilai $f$ square sebesar 1,754 dan termasuk ke dalam indikator yang memiliki effect size sedang karena nilai $f$ square empathy lebih besar apabila dibandingkan dengan 0,15. Sedangkan untuk keempat indikator lainnya memiliki nilai effect size rendah.

c. Nilai Path Coeffcient 
Nilai path coefficient model digunakan untuk menunjukkan besarnya pengaruh dari masing-masing konstruk. Berikut merupakah hasil nilai path coefficient :

Tabel 8. Hasil nilai path coefficient

\begin{tabular}{|l|c|}
\hline \multicolumn{1}{|c|}{ Indikator } & $\begin{array}{c}\text { Kualitas Layanan Internet } \\
\text { Indihome }\end{array}$ \\
\hline Assurance & $-0,172$ \\
\hline Empathy & 0,766 \\
\hline Reliability & 0,216 \\
\hline Responsiveness & 0,186 \\
\hline Tangible & $-0,004$ \\
\hline
\end{tabular}

Berdasarkan tabel 8 dapat diketahui jika indikator empathy memiliki nilai path coefficient sebesar 0,766 yang menunjukkan bahwa indikator tersebut berpengaruh kuat positif terhadap kualitas layanan internet indihome, semakin kuat aspek empathy maka akan semakin meningkat pula kualitas layanan internet indihome. Indikator reliability dan responsiveness juga memiliki nilai positif namun tidak signifikan, sementara untuk indikator assurance dan tangible memiliki nilai negatif namun tidak signifikan.

Berikut merupakan model akhir PLS yaitu hasil dari penyempurnaan kekurangan yang ada pada model awal dengan langkah menghilangkan indikator yang tidak memenuhi syarat PLS. Dapat diketahui pula setelah menghilangkan indikator A5 dari model awal maka nilai $R$ square pada model akhir lebih besar apabila dibandingkan dengan model awal.

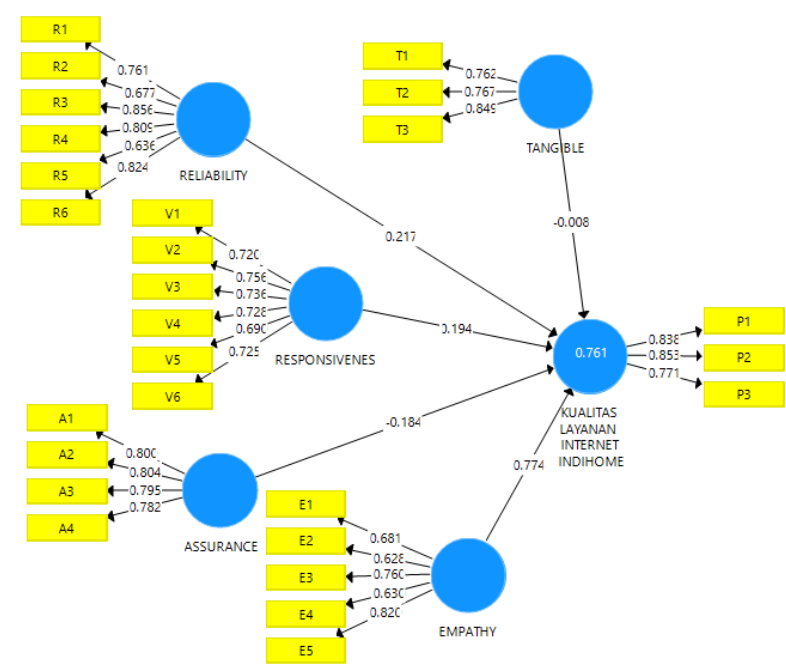

Gambar 3. Hasil model akhir PLS

Dari gambar 3 dapat dilakukan perbandingan antara model awal PLS dengan model akhir PLS:

Tabel 9. Perbandingan model PLS

\begin{tabular}{|c|c|c|c|}
\hline $\mathrm{No}_{0}$ & Perbandingan & Model Awa & Model Akhir \\
\hline 1 Nilai R Square & Kualitias layanan internet Indihome & 0.76 & 0.761 \\
\hline 2 Path coefficient & Empathy -> Kualitas layanan internet Indihome & 0.766 & 0.774 \\
\hline 3 fsquare & Empathy & 1.754 & 1.746 \\
\hline
\end{tabular}

Berdasarkan tabel 9 dapat diketahui jika model akhir PLS pada path coefficient empathy ke kualitas layanan internet Indihome dapat menjelaskan sebesar $77,4 \%$ dengan nilai $f$ square sebesar 1,746 memiliki effect size yang kuat.

\section{d. Pengukuran Goodness Of Fit}

Goodness Of Fit digunakan untuk menilai secara keseluruhan model (model pengukuran dan model struktural). Penilaian GOF adalah dengan memperhatikan nilai GOF, apabila GOF bernilai 0,1 maka dapat dikatakan GOF small, apabila bernilai 0,25 maka dapat dikatakan medium dan apabila bernilai 0,36 maka dapat dikatakan large .

Berikut merupakan perhitungan nilai GOF model PLS:

$$
\begin{aligned}
& G O F=\sqrt{\text { Communality } x R^{2}} \\
= & \sqrt{\left(\frac{0,632+0,501+0,675+0,584+0,527+0,630}{6}\right) \times 0,761}
\end{aligned}
$$




$$
\begin{aligned}
& =\sqrt{\left(\frac{3,549}{6}\right) \times 0,761} \\
& =\sqrt{0,592 \times 0,761} \\
& =\sqrt{0,451} \\
& =0,672
\end{aligned}
$$

Berdasarkan perhitungan nilai GOF didapatkan nilai sebesar 0,672 yang berarti bahwa model PLS yang dibuat dapat dikatakan prediksi model secara keseluruhan baik.

\subsubsection{Pengujian Hipotesis}

a. Tangible

$\mathrm{H}_{0}$ : Tidak terdapat hubungan antara tangible dengan kualitas layanan internet indihome

$\mathrm{H}_{1}$ : Terdapat hubungan antara tangible dengan kualitas layanan internet indihome

Pengambilan keputusan :

Jika p-value $\leq 0,05$ maka tolak $\mathrm{H}_{0}$

Jika p-value > 0,05 maka terima $\mathrm{H}_{0}$

Nilai p-value tangible adalah sebesar 0,895 dan lebih besar dari 0,05 maka terima $\mathrm{H}_{0}$ yang menandakan bahwa tidak ada hubungan antara tangible dengan kualitas layanan internet indihome.

b. Reliability

$\mathrm{H}_{0}$ : Tidak terdapat hubungan antara reliability dengan kualitas layanan internetindihome

$\mathrm{H}_{1}$ : Terdapat hubungan antara reliability dengan kualitas layanan internetindihome

Pengambilan keputusan :
Jika p-value $\leq 0,05$ maka tolak $\mathrm{H}_{0}$

Jika p-value > 0,05 maka terima $\mathrm{H}_{0}$

Nilai $p$-value reliability adalah sebesar 0,015 dan lebih kecil dari 0,05 maka tolak $\mathrm{H}_{0}$ yang menandakan bahwa terdapat hubungan antara reliability dengan kualitas layanan internet indihome.

c. Responsiveness

$\mathrm{H}_{0}$ : Tidak terdapat hubungan antara responsiveness dengan kualitas layanan internetindihome

$\mathrm{H}_{1}$ : Terdapat hubungan antara responsiveness dengan kualitas layanan internetindihome

Pengambilan keputusan :

Jika p-value $\leq 0,05$ maka tolak $\mathrm{H}_{0}$

Jika p-value $>0,05$ maka terima $\mathrm{H}_{0}$

Nilai p-value responsiveness adalah sebesar 0,060 dan lebih besar dari 0,05 maka terima $\mathrm{H}_{0}$ yang menandakan bahwa tidak ada hubungan antara responsiveness dengan kualitas layanan internet indihome.

d. Empathy

$\mathrm{H}_{0}$ : Tidak terdapat hubungan antara empathy dengan kualitas layanan internet $\mathrm{H}_{1}$ : Terdapat hubungan antara empathy dengan kualitas layanan internet

Pengambilan keputusan :

Jika p-value $\leq 0,05$ maka tolak $\mathrm{H}_{0}$

Jika p-value $>0,05$ maka terima $\mathrm{H}_{0}$

Nilai p-value empathy adalah sebesar 0,000 dan lebih kecil dari 0,05 maka tolak $\mathrm{H}_{0}$ yang menandakan bahwa terdapat hubungan antara empathy dengan kualitas 
layanan internet indihome

e. Assurance

$\mathrm{H}_{0}$ : Tidak terdapat hubungan antara assurance dengan kualitas layanan internetindihome

$\mathrm{H}_{1}$ : Terdapat hubungan antara assurance dengan kualitas layanan internetindihome

Pengambilan keputusan :

Jika p-value $\leq 0,05$ maka tolak $\mathrm{H}_{0}$

Jika p-value $>0,05$ maka terima $\mathrm{H}_{0}$

Nilai p-value assurance adalah sebesar 0,036 dan lebih kecil dari 0,05 maka tolak $\mathrm{H}_{0}$ yang menandakan bahwa terdapat hubungan antara assurance dengan kualitas layanan internet indihome.

\section{Kesimpulan dan Saran}

Dari hasil penelitian maka dapat diketahui bahwa dalam peningkatan kepuasan pelanggan dan peningkatan pelanggan produk internet indihome maka dilakukan analisis dari segi kualitas pelayanannya meliputi tangible, reliability, responsiveness, empathy dan assurance. Dari kelima variabel tersebut berdasarkan hasil uji hipotesis maka memberikan pengaruh yang signifikan terhadap kualitas pelayanan. Dalam penelitian ini perlu dilkukan pengembangan pada penelitian selanjutnya untuk menganalisis variabel lain untuk kualitas pelayanan selain dari lima variabel yang sudah dilakukan.

\section{DAFTAR PUSTAKA}

Mardiana, I. and Rubiyanti, R.N., 2017. Analisis Kepuasan Pelanggan Berdasarkan Dimensi Servqual Menggunakan Metode Importance Performance Analysis (Studi Pada Indihome Witel Bandung). Jurnal Ekonomi, Bisnis \& Entrepreneurship, 11(1), pp.47-58.

Nugroho, N.T., 2014. Pengaruh Kualitas Pelayanan Terhadap Kepuasan Dan Loyalitas Pelanggan (Survey Pada Pelanggan Speedy Telkom Di Kota Surakarta). Jurnal Paradigma Universitas Islam Batik Surakarta, 12(02).

Amatullah, F.A. and Widaningsih, S., 2017. Analisis Kepuasan Pelanggan Indihome Pada Wilayah Kenten Sako, Palembang (study Kasus Di Pt. Telkom Indonesia Tbk, Witel Sumsel 2017). eProceedings of Applied Science, 3(2).

Ismail Razak, S.E. and Finnora, E., 2017. Pengaruh Kualitas Layanan Dan Citra Perusahaan Terhadap Kepuasan Nasabah. Jurnal Manajemen Bisnis Krisnadwipayana, 5(2).

Pertiwi, M.A., Pengaruh Kualitas Layanan Terhadap Kepuasan Dalam Membentuk Loyalitas Pelanggan (Studi pada Tempat Makan CFC di Kota Semarang).

Gulla, R., Oroh, S.G. and Roring, F., 2015. Analisis Harga, Promosi, dan Kualitas pelayanan terhadap Kepuasan konsumen pada hotel Manado Grace inn. Jurnal EMBA: Jurnal Riset Ekonomi, Manajemen, Bisnis dan Akuntansi, 3(1).

Panjaitan, J.E. and Yuliati, A.L., 2016. Pengaruh Kualitas Pelayanan Terhadap Kepuasan Pelanggan Pada JNE Cabang Bandung [The Influence of Service Quality on Customer Satisfaction at JNE Branch in Bandung]. DeReMa (Development Research of Management): Jurnal Manajemen, 11(2), pp.265-289.

Putri, M.N. and Widodo, A., 2016. Pengaruh Kualitas Pelayanan Terhadap Kepuasan Pelanggan Indihome Pada Wilayah Antapani Kota Bandung. eProceedings of Management, 3(3).

Bailia, J.F., Soegoto, A.S. and Loindong, S.S.R., 2014. Pengaruh Kualitas Produk, Harga Dan Lokasi Terhadap Kepuasan Konsumen Pada WarungWarung Makan Lamongan Di Kota Manado. Jurnal EMBA: Jurnal Riset Ekonomi, Manajemen, Bisnis dan Akuntansi, 2(3).

Moha, S. and Loindong, S., 2016. Analisis kualitas 
pelayanan dan fasilitas terhadap kepuasan konsumen pada Hotel Yuta di kota Manado. Jurnal EMBA: Jurnal Riset Ekonomi, Manajemen, Bisnis dan Akuntansi, 4(1).

Ghozali, Imam. 2014. Structural Equation Modelling Metode Alternatif dengan Partial Least Square (PLS). Semarang. Universitas Diponegoro.

Sholihin, Mahfud dan Ratmono, Dwi. 2013. Analisis SEM-PLS dengan WarpPLS 3.0 untuk Hubungan Nonlinier dalam Penelitian Sosial dan Bisnis. Yogyakarta. Penerbit : CV. ANDI Offset.

Shandyastini, N.M. and Novianti, K.D.P., 2016. Analisis E-Learning Stmik Stikom Bali Menggunakan Techonology Acceptance Model. Jurnal TeknoIf, 4(2). 